\title{
ANIMAL FARM REVISITED: AN ENVIRONMENTAL ALLEGORY
}

\author{
Bruce Pardy*
}

In 1945, George Orwell wrote Animal Farm, a story about barnyard animals who overthrow their tyrannical human master but end up creating an equally oppressive hierarchy. "All animals are equal", reads the seminal line in the book, "but some animals are more equal than others". Animal Farm was an allegory about the Soviet Union under Stalin, although Orwell intended it to have wider application also. "It is" wrote Orwell in the blurb for the first edition, "the history of a revolution that went wrong - and of the excellent excuses that were forthcoming at every step for the perversion of the original doctrine". In "Animal Farm Revisted" Orwell's template has been applied to the environmental question. In a multitude of countries, including New Zealand, and in the international sphere, environmental law suffers from a plethora of good intentions and a paucity of concrete principles. Indeed, the history of environmental protection could be described as the story of an intention gone astray - and of the excellent explanations that have been forthcoming for the qualification of its purpose. "Animal Farm Revisited" is a kind of environmental Rorschach test: at what moment do actions become environmentally inappropriate? Many answers are possible. The story is not specifically about the Resource Management Act 1991, but its themes are relevant to the Act and its interpretation.

Mr Jones, of the Manor Farm, had locked the hen-houses for the night. With the circle of light from his flashlight dancing from side to side, he strode across the yard, kicking off his boots at the back door, and made his way up to bed.

At one end of the big barn, on a sort of raised platform, was old Major, the prize Middle White boar. It had been agreed amongst the farm animals that they should all meet as soon as Mr Jones was safely out of the way to hear what Major had to say. When he saw that the other animals had all made themselves comfortable and were waiting attentively, Major cleared his throat and began:

* Senior Lecturer in Law, Faculty of Law, Victoria University of Wellington. The author thanks Bill Atkin and Geoff McLay of the Faculty of Law, Victoria University of Wellington and Paula Lustbader of the School of Law, Seattle University, for their constructive criticism and comments. 
"I do not think, friends, that I shall be with you for much longer. Before I die, I feel it my duty to pass on to you such wisdom as I have acquired. I have had a long life, and I think I may say that I understand the nature of life on this farm as well as any animal now living. It is about this that I wish to speak to you.

"What is the nature of life on this farm? Let us face it: it is the wanton destruction of life itself. We are born creatures of nature, as pure as the earth that we were born to; but our lives are not natural at all. We live only to produce. We are stored in small pens. We are pumped full of potions. On this farm, the laws of nature are broken. The land is abused. The soil is exhausted. The water is spoiled. The forests are cut. The wild animals who live in those woods are starved. We are squeezed to the edge of tolerance by human beings.

"Humans are the only creatures that destroy what supports them. They bite the hand that feeds them. They disrespect the systems that keep them alive. These matters cannot continue. Soon the water will be undrinkable. The fields will produce less feed. We will become infected with resistant diseases. The forest will be destroyed. Perhaps not this year. Perhaps not next year. But someday, surely as I sit before you.

"This is my message to you, friends: Revolution! I do not know when that Revolution will come, it might be in a week or in a hundred years, but I know, as surely as I see this straw beneath my feet, that sooner or later environmental justice will be done."

Major continued, "Remember that in struggling against human ways, we must learn not to repeat them. Do not adopt their methods. Do not cut down the forests. Do not develop the land. Do not exhaust the soil. Do not dirty the water. No animal must ever forget that he is dependent on the ecosystem that he lives within."

Two nights later old Major died. His body was buried at the foot of the orchard.

During the next three months there was much secret activity. Major's speech had given to the more intelligent animals a completely new outlook on life. The work of teaching and organizing the others fell naturally upon the pigs, who were generally recognized as being the cleverest of the animals. Pre-eminent among the pigs were two young boars named Snowball and Napoleon. Napoleon was a large, rather fiercelooking billy pig, with a reputation for getting his own way. Snowball was a more vivacious pig than Napoleon, quicker in speech and more passionate, but was not considered to have the same depth of character.

The two had elaborated old Major's teachings into a complete system of thought, to which they gave the name of Environmentalism. Several nights a week, after Mr Jones was asleep, they held secret meetings in the barn and expounded the principles of Environmentalism to the others. At the beginning they met with such stupidity and 
apathy. Some of the animals talked of the duty of loyalty to the farm, how it provided them with food and a place to sleep.

The pigs had an even harder struggle to counteract the lies put about by Moses, the tame raven. He claimed to know of a system of knowledge that required the farm to be run the way it was. He said that unless the farm continued to expand and develop, that unless the crop yield increased and the amount of eggs, milk and wool continued to grow, that the farm would collapse and the animals would perish. He said that the harm to the land and the water and the forest was a natural thing, and that the resources on the farm were so vast that their limits would never be reached. The animals hated Moses because he told tales and did not work, but some of them believed what he said about the farm, and the pigs had to argue very hard to persuade them that it was not correct.

As it turned out, the Environmental Revolution was achieved much earlier and more easily than anyone had expected. In past years Jones had been a capable farmer, but of late his fortunes had fallen. His crop yields had declined and he was behind on his loan payments to the bank.

It was late summer. Jones and his farm hands sprayed the orchard, wheeling containers of pesticide behind them, spreading spray from a hose like firefighters shooting water at a blaze. They wore protective gear to keep out the fumes. There was no such protection for the animals. The crew simply poured the residue into the stream. The animals' water was drawn from a well fed by the stream. When the thirsty animals were watered later that day, the water was undrinkable, contaminated with the pesticide. They endured a long, parched night. When the containers were refilled the next morning with the same contaminated supply, they could stand it no longer. One of the cows broke through the latch of one of the pasture gates, and the animals headed for the stream, hoping for a clean drink. It was just then that Jones came around the corner of the house. The next moment he and his men were in the yard with whips in their hands, lashing out in all directions. This was more than the thirsty animals could bear. They flung themselves upon their keepers. Jones and his men suddenly found themselves being butted and kicked from all sides. This sudden uprising of creatures frightened them almost out of their wits. After only a moment or two they gave up trying to defend themselves and took to their heels. Moses sprang off his perch and flapped after them, croaking loudly. The animals chased them out onto the road and slammed the gate behind them. And so, almost before they knew what was happening, the Revolution had been successfully carried through: Jones was expelled, and Manor Farm was theirs.

For the first few minutes the animals could hardly believe in their good fortune. Their first act was to gallop in a body right round the pasture, up to the edge of the forest; then they raced down to the stream. Being careful to go as far upstream as they could, near 
where the water bubbled out of the ground, they helped themselves to a long, clean drink.

The pigs now revealed that during the past three months they had taught themselves to read and write from an old spelling book which had belonged to Jones's estranged children. Napoleon sent for pots of black and white paint and led the way down to the front gate of the farm on the main road. Then Snowball took a brush between the two knuckles of his trotter, painted out MANOR FARM from the top bar of the gate and in its place painted ANIMAL FARM. This was to be the name of the farm from now onwards. After this they went back to the farm buildings, where Snowball and Napoleon sent for a ladder which they caused to be set against the end wall of the big barn. They explained that by their studies of the past three months the pigs had succeeded in reducing Environmentalism to Six Principles. These Six Principles would now be inscribed on the wall; they would form an unalterable law by which all the animals must live. With some difficulty Snowball climbed up and set to work, with a small pudgy pig named Squealer a few rungs below holding the paint-pot. The Principles were written on the tarred wall in great white letters that could be read thirty metres away. They ran thus:

\section{THE SIX PRINCIPLES}

1. Whatever sustains the natural world is a friend.

2. Whatever develops, damages and destroys the natural world is an enemy.

3. Everything is connected to everything else.

4. All animals depend on ecosystems.

5. All animals are part of ecosystems.

6. No animal shall change an ecosystem.

Snowball read it aloud for the benefit of the others. All the animals nodded in complete agreement, and the cleverer ones at once began to learn the Principles by heart.

How the animals toiled and sweated to get the corn in! But like the previous three years at Manor Farm, the harvest was smaller than the year before.

"It is not our fault," said Snowball, "Jones did not look after the land. He planted the same crop year after year in the same fields, and the soil is exhausted. It has no more nutrients to give. We will do things differently so that the land recovers. First we must correct the damage that Jones has caused."

Snowball read out the first two principles. "We must not develop, damage or destroy the natural world, but sustain it. This means that anything we do must not have a permanent effect." 
Some of the other animals were not sure what this meant. Why do anything that has no effect? "You misunderstand," said Snowball, "It can have a temporary effect as long as it causes no permanent change to natural systems. We harvested corn from the fields. Harvesting corn was a good thing to do because it did not cause any permanent change to the land. It did not harm any animals. It did not spoil any water. These are the only kinds of things that will happen on this farm from now on."

"Look at the Fifth Principle. It says that all animals are part of ecosystems. That means that when we live in the right way, we are just part of the system. We eat nothing that does not grow back. We take nothing that is not replenished. We create no waste. What do you think manure is? It is fertilizer. It returns food to the earth and makes things grow again. Our effects are just part of the system."

The pigs set about to educate the rest of the animals more properly on the principles of Environmentalism. It was found that the stupider animals were unable to learn the Six Principles by heart. After much thought Snowball declared that the Six Principles could in effect be reduced to a single maxim, namely: "Sustainability good, Development bad." This, he said, contained the essential principle of Environmentalism. Whoever had thoroughly grasped it would be safe from causing damage to natural systems. All the humbler animals set to work to learn the new maxim by heart. SUSTAINABILITY GOOD, DEVELOPMENT BAD, was inscribed on the end wall of the barn, above the Six Principles and in bigger letters.

Napoleon said that the education of the young was more important than anything that could be done for those who were already grown up. It happened that the cat had given birth to five fluffy kittens, just after the harvest. As soon as they were weaned, Napoleon took them away from their mother, saying that he would make himself responsible for their education. He took them up into one of the bedrooms in the farmhouse, and there kept them in such seclusion that the rest of the farm soon forgot their existence.

The state of the property was as the pigs had expected. Years of growing the same crop on the same land year after year had left the soil depleted of nutrients. Spraying had resulted in pesticide and herbicide residues to run off into the pond near the orchard. Some of the chemicals had also seeped into the ground - trace amounts were in the groundwater. Ten acres of mature forest had been clear cut and sold to a paper company. The loss had caused great hardship among the residents of the forest. Displaced animals had moved into their neighbours' territories and conditions were tight. It was also found that the farm's pasture lands were close to exhaustion. Not enough time had been given for the grass to replenish itself before Jones sent the animals back to the same fields. 
"We will allow the forest that has been cut to grow back as best as it can. The spraying of the orchard will stop immediately. The pond is off-limits to all animals," Snowball said. There was a whining of discontent at this announcement. Some of the animals, especially the dogs, liked to go for swims in the pond on hot days, and it was a popular place for a quick drink. Neither Snowball nor Napoleon mentioned the contamination of the groundwater. Although they were alarmed to have discovered it, they did not think the trace elements would actually hurt anyone. The groundwater fed the stream and well, and there was no other source of water on the farm.

"Our duty is to preserve ecosystems on this farm in their natural state," reminded Snowball, "and where humans have damaged them, to put them back to their natural state as closely as we can. Sometimes that will require some sacrifice from us. For instance, we must be careful with how much corn we eat because there will be no new crop next year."

That caused a flutter. "What will we eat?"

"There will be enough corn. Jones sold most of his corn crop, but we will not do that. The preservation of the land is more important than selling crops for money. We will keep all the corn for next year."

"Why can't we put the farm in whatever way is best for us?" said one of the animals, "The original forest is gone. So why can't we grow corn there?"

"You are forgetting the Third Principle! Everything is connected to everything else. We cannot treat some parts of the farm as Jones did, simply for our own benefit, and expect the other parts not to be affected. Growing corn has damaged the soil, poisoned the water! We must protect the system. Everything is connected to everything else. A healthy farm, with clean soil and clean water is closer to the original state of this land than a poisoned farm, with damaged soil and dirty water - and sick animals! You do not want to be made sick by doing what Jones did, do you?"

The animals agreed they did not want to be sick, and they did not want to do what Jones used to do. But they were not sure what that meant. What, of the things they used to do, could they still do? Snowball began to get exasperated at their stupidity. "It is very simple. You can do anything that does not change the system. Act so that you are part of the system, instead of a burden on it. For example, do not relieve yourselves in your pens. That is not the proper place for it. That is the meaning of dirt, something that is not where it is supposed to be. Instead, take to the fields! Help them rejuvenate. Fertilize them. Do not produce anything that must be thrown away. When you eat, eat well, but not so as to destroy the plant you graze from. Eat the new growth, and then leave it alone to grow back so it will feed you again. Ask yourself: will what I am doing affect the way the system works? If the answer is yes, don't do it! Ask yourself, will 
what I am doing help the system work? If the answer is yes, you are following the Sixth Principle: No Animal shall change an ecosystem."

Autumn approached, and life on the farm continued much as before, except that the animals avoided the pond. The apples had ripened, and were falling to the ground in vast quantities. They animals collected as many as they could in baskets, buckets and boxes and put them in cold storage for leaner times.

The pigs were not sure what to do about the farm's pastures. Every day the sheep, cows and horses grazed on fields that had not yet recovered. Blades of grass were getting so short that it was difficult to bite any without picking up dirt. But they could not wait without going hungry. Apples would do for a little while, but they did not want to deplete their winter food supply.

Then they made a discovery. Just outside Animal Farm, near the farthest corner of the property beyond the creek, was a vacant field. It was part of Foxwood, a neighbouring farm. Since the death of its owner, Mr Pilkington, the farm had been abandoned. Apparently Pilkington's sons were not interested in farming but had not yet sold the property. The grass was long, and the land was healthy. The cows and sheep were sent to graze the commons that very afternoon.

The next morning, the dogs ran to the farmhouse in a panic, barking furiously. Humans were approaching. A man and a woman had parked a car on the road and were walking to the main gate. Obviously they were going to attempt the recapture of the farm.

"We represent the Bank of New Britain," the woman announced, and took an envelope from her briefcase. She took a sheath of papers out of the envelope. "This is formal notice which we are hereby serving upon you that loan payments from this farm are six months in arrears. The bank holds a mortgage on this property as security for the loan. Unless payment is made forthwith, the bank will rely on its security to recover the outstanding amount of principal and interest owing."

They bowed slightly to the pigs. "Good day, " they said, and left.

The animals gathered round the two pigs, everyone asking questions at once. Who were those people? What did they want? Were they sent by Jones to get the farm back? The dogs said they should have attacked them, and not let them on the property.

"Friends, please!" Napoleon bellowed, "These people were not sent by Jones, not exactly. They were sent by the bank. A bank is where humans keep money," Napoleon said, "The ones who don't have money go to the bank to get some. That's what Jones did, it looks like," he lay on the porch and flipped through the pages with his hoof. "When 
you get money from one of these banks, you have to give it back later. If you don't give it back, they take something else away from you."

"Give it back?" intoned Benjamin the dour donkey, swishing his tail slowly from side to side, "Why bother getting it in the first place?"

Napoleon studied the papers. "This says that Jones didn't give back the money when he was supposed to. And it says that because he didn't give it back, the bank can take the farm and sell it, in order to get the money."

Meanwhile, the Foxwood pasture had become crowded. Other farms had heard about the empty field and it was empty no longer. Snowball declared that they would not feed there any more. The others were disappointed, for although the grass at Foxwood was now disappearing quickly, it was still more lush than the fields of Animal Farm.

Snowball berated them for their selfishness. "Can you not see what is happening? All the farmers have put animals on this pasture. It is being overgrazed, and soon will be consumed completely. We have a responsibility to that land as much as to the land of Animal Farm. We must treat that pasture sustainably! That does not mean eating it up as fast as we can, competing with all those animals from other farms."

"But the other animals will graze there whether we do or not, won't they?" said Napoleon.

"They probably will," Snowball admitted.

"And if they do, the pasture will be exhausted whether we graze there or not?"

"That is not the point! The point is that we must govern our own affairs according to the Principles of Environmentalism. We must do the right thing."

Napoleon acquiesced, and Snowball's declaration was followed.

It was a blustery autumn evening. The animals gathered in the big barn. Napoleon was lying comfortably in some hay, while Snowball paced around a corner of the barn, his tail twitching.

"Jones, our former master, owes money to a bank," Napoleon said, "If the money is not paid, the bank will take this farm, and sell it. The Principles of Environmentalism will no longer be applied. We have two choices: We can lose the farm. Or we can pay the money to the bank."

"There is another choice!" cried Snowball, and stomped his hoofs. "We refuse! We have set out our own rules! We refuse to cooperate."

At this there was a great noise of approval. Napoleon cleared his throat. 
"If we do not pay the money, the bank will claim the farm. Even if we reject the claim, humans will arrive. They will have guns. When we have run to the forest for our lives, they will come to hunt us down. They will not shoot us, not if we agree to come back to our stalls with the locked gate. They will plant more corn in our fields. They will spray our orchards. They will give us dirty water. They will cut down the forest."

There was a collected muttering of voices. "We will pay the bank!" grunted Muriel the white goat, "But how can we get money without breaking the Principles?"

"We do it in order to follow the Principles!" Napoleon startled them with his sudden bellow, "Survival is the highest Principle of all. It is our First Principle: Whatever sustains the natural world is a friend. We are part of ecosystems. Sustaining the natural world includes sustaining our own lives. Survival is the most basic form of sustainability! It is the first rule of nature. The struggle to survive is what makes natural systems work!

"We thought that we had chased Jones away, but it was really the bank that made him leave. He ran from us, but it was debt that kept him away. He was about to lose this farm anyway. We have it, but the bank holds it. Some day, all the earth will be treated like Animal Farm. But not yet. This will require sacrifice from all of us. We will have to sell some goods: corn, apples, milk, wool, and eggs."

The hens squawked in protest. "They will be our children! We will not give up our children!"

"You already have too many children. They are eating all the corn," Napoleon said, "You will do no more than you were doing before."

In winter, there came bitterly cold weather. The sheep had been shorn. They now shivered in the cold, and spent as much time as possible inside the barn. The wool, most of the corn and apples, all of the accumulated milk, and as many freshly laid eggs as were available had been sold. The money had been sent to the bank. A receipt arrived in the mail, acknowledging that the loan was in good standing.

One month later, Snowball told the animals that another demand note had been received, as well as a bill from the power company. "You see," he cried, "It is never enough. Humans are never satisfied. They require us to break the Principles."

Napoleon did not agree. "This is the way it works. Every month there is a small payment owed to the bank. The payment that we made before was large, because Jones had not paid the bank for many months. We are already over the crisis - every payment from now on will be small. And paying money has worked, has it not? Other than the people who came to buy our goods, have you seen any people at this farm? None, not since the two bankers were here months ago." 
"How are we to make the next payment?" demanded Snowball, "We have only enough corn and apples to feed ourselves. The sheep have no wool to give. Milk and eggs alone will not be enough."

"Whatever we do, be sure it will be done sustainably!" said Napoleon, "We will sell some wood."

"Some wood?!" repeated Snowball, "Have you forgotten everything so fast? We stopped cutting the forest because it was being destroyed. The animals who live there are struggling to survive. You want to cut more down?"

Napoleon shook his head, "We do not cut any more forest in the way it has been cut in the past. Before, it was simply cut down without any regard for the impact, in large areas. It was cleared off and destroyed. But there is another way. We do it in a way which obeys all the Principles." At this moment, Napoleon stood up and uttered a highpitched whimper of a kind no one had ever heard him make before.

At this there was a chorus of mewing from outside, and five cats walked through the door into the barn. At first no one recognized them or could figure out where they came from, but the problem was soon solved: they were the kittens that Napoleon had taken away from their mother and reared privately. He had taken them to a room in the farm house where he had put them in the top drawer of a bureau. Though not yet fully grown, the bureau cats were now a good size.

"These cats have spent most of their young lives devoted to the study of Environmentalism and its associated sciences," Napoleon explained, "I started their training myself. Their expertise will be invaluable to us to make sure that we never break the Principles of Environmentalism ."

He turned to one of the cats. "This is Medea," he said, "Medea, we have been discussing the sustainable harvest of lumber. Could you explain to us how that can be done?"

The cat twitched her whiskers, and bounded up to sit on Napoleon's shoulder. "The harvesting of single trees cut no less than 20 metres apart in largely deciduous old growth forest has not been shown to have any permanent change on forest ecosystems. Forest communities are generally able to be accommodated by remaining trees. The harvested trees will be replaced by naturally occurring new growth over time."

"You see," said Napoleon, "It can be done. Look at the Sixth Principle - No animal may change an ecosystem. The Principles do not say we cannot harvest trees. We can harvest trees in any way which does not change the system. We cut trees selectively, in different places, so that it does not affect how the system works. That is sustainable forestry." 
And so it was agreed, since the harvest of the trees would not break any of the Principles, that it could proceed in the way Medea had described.

Because the grazing animals had been brought back to the fields of Animal Farm, the grass on these fields, which had not completely recovered, began to deteriorate again. Snowball determined that the farm's supply of corn and apples was not sufficient to carry them over until the fields would be ready again. Animals from other farms still grazed on the abandoned field. Some other place would have to be found.

There was pastureland on the other side of the north woods which belonged to Pinchfield Ranch. Pinchfield agreed to rent the land to Snowball, and the horses, cows and sheep made the long trek each morning and evening. The land was obtained for a reasonable rent, but nearly all the money that Animal Farm had earned from its goods was taken for the payments to the bank and the power company. Money for the rent would have to be found. Snowball decided that since the field was feeding the cows and sheep, it should be considered as a cost of producing the farm's milk and wool. The price would be raised to reflect the additional cost.

During the winter months many meetings were held in the big barn. It had come to be accepted that the pigs, guided by the expertise from the cats, decided what could and could not be done on the farm under the Principles of Environmentalism. Major issues were ratified by majority vote of all the farm animals. This arrangement might have worked well enough if it had not been for the disputes between Snowball and Napoleon. Ever since the crisis about the bank debt, these two had disagreed. Nearly always the topic concerned whether some proposed activity should be permitted under the Principles of Environmentalism, and nearly always one of the bureau cats was an expert on the kind of impact the activity would cause.

Of all their controversies, none was so bitter as the one that took place over the dam. A mile downstream from where the spring gushed out of the ground, the stream on the farm flowed over a steep drop of rock. At this point the stream was almost a small river, being a good several metres across. After surveying the waterfall, Napoleon declared that it was just the place for a dam and mini-generating station, which could be made to supply the farm with electrical power. This would eliminate their dependence upon the humans' power grid, and save them from having to pay electricity bills each month.

The whole farm was deeply divided on the subject. Napoleon did not deny that to build it would be a difficult business. Stone would have to be quarried and built up into the barrier for the dam. Turbines and cables would have to be rigged within the wall to take the water's force and turn it into electricity. (How these were to be procured Napoleon did not say.) Napoleon maintained that the dam would help Animal Farm end its dependence on harmful human systems. If they produced their own power, they 
would no longer be dependent on human supplies. The dam did not pollute anything, unlike the other ways they might power the farm, such as burning fuel or trees. Snowball, on the other hand, argued that the dam was a crime against Environmentalism, that it would cause the flooding of an area of woods surrounding the stream, and thereby damage the forest and stream ecosystems. The animals formed themselves into two factions under the slogans, "Vote for Napoleon and self-sustainability" and "Vote for Snowball and preservation of ecosystems". Benjamin was the only animal who did not side with either faction. He refused to believe either that the dam would make the farm environmentally independent or that the alternatives were environmentally harmless. Dam or no dam, he said, life would go on as it had always gone on - that is, badly.

At last the day came when Napoleon's plans were completed. When the animals had assembled in the big barn, Snowball set forth his reasons why the dam should not be built. A dam, he said, was exactly the kind of thing that Environmentalism was designed to prevent. It would create a permanent change to the forest ecosystem. The fact that the dam would produce power for years to come did not make it sustainable. The system that was supposed to be sustained was the one that now existed, the natural one, not the system that would exist after the dam was finished. The very notion of building a permanent facility to harness the forces of nature, and thereby change them, was directly contrary to the Principles that all animals are part of ecosystems, that all animals depend on ecosystems (as they are, Snowball declared) and that no animal shall change an ecosystem. Furthermore, to allow the dam to proceed would be a crime against the forest animals, who were already desperate for space. Snowball concluded by saying that he was ashamed that they were even contemplating such a thing.

Napoleon stood up and replied, "Snowball means well, but he has misunderstood the Principles of Environmentalism. The real world is a complex place. Snowball would have you believe that everything is black and white - a thing is a good thing, or it isn't. The real world doesn't work like that. Environmentalism requires difficult choices! The only thing we can be sure of is that we must act in the best interests of the environment. We must sustain it! But what does that mean?

"The environment is everything we have around us. The soil and the water, the forest and the orchard. It is also the farm buildings, the barn, the pens, the farmhouse, and the well. It is also our beliefs, our traditions and our relationships, our standard of living, our prosperity. It is everything. It includes the physical world, and our social world as well. Are these not among the most important aspects of our lives? The Principles say that we must act on this farm so as not to harm the environment. But in order to do that, we must weigh many factors. We do not want to stop something that will improve our lives, for that would be acting to the detriment of our environment on this farm. 
"Snowball has urged caution, and I say that Snowball is right! Where the environment is concerned, everything must be done carefully! I know that many of you share his concerns about a project like the dam, and you are right to be concerned. You are right because it is difficult to know what life will be like when the dam is finished. That is why we should not decide today whether to build the dam or not. We do not have enough information! And even if we did, we probably would not have the skill to evaluate it properly. We would cause conflict amongst ourselves, and we would just be guessing! There is a better way. We should refer this question to those among us who have the skills and the time to look at all the facts carefully, and can recommend to us what should be done."

This proposition caught Snowball by surprise. He did not like it. "The decision to be made is perfectly clear! A dam will damage ecosystems! That is not in dispute. What more expertise do we need to know that it is contrary to Environmentalism?!"

"Let us not jump to conclusions. Snowball would decide this important question for you, rashly," Napoleon soothed, "Would you not prefer to wait and have all the facts? Would you not prefer to know whether there will be a net benefit? Would you not prefer to know whether there will be an improvement in your lives? Let us review it for environmental impact. Nothing should be allowed to be built on this farm without an environmental impact review. Jones would have ignored the possibility of harm. Instead, we will investigate thoroughly to determine the risks and benefits - taking everything into consideration before we allow a project to proceed."

Napoleon cast his eyes around the room. "Is there anyone who objects to a more careful consideration of this question, by those who know how?" There was no reply.

The animals gathered at the end of the big barn where the Principles were painted. "Jessie," said Boxer, an enormous work horse, to one of the dogs who was an able reader, "Read the Principles for us."

Jessie sat on his hind legs and looked up at the wall. With his panting tongue darting in and out, he read:

1. Whatever sustains the environment is a friend.

2. Whatever develops, damages and destroys the environment is an enemy.

3. Everything must be considered before action is approved.

4. All animals depend on the environment.

5. All animals are part of the environment.

6. No animal shall change the environment. 
"Are they different?" said one of the cows, "They sound different, but I cannot remember."

"Some words have been changed," said Jessie, still panting, "The word 'environment' has been traded for other words that were there before."

"But it says everything must be considered," said Muriel, "so that doesn't leave anything out. It must be a way to be extra specially careful."

About a week later, the animals gathered in the barn to hear the report prepared by the cats on whether the dam should be built. Medea perched herself on a barrel at the front.

"The committee assigned to this task is pleased to make its report to the animals of the farm," she said, "During the course of our assessment, we conducted surveys of the forest, made projections of energy needs for the farm, considered possible markets for excess power, invited input from all interested animals of the farm, and obtained technical information from the designer of the project." She waved a paw in Napoleon's direction.

"Invited input?" bleated a sheep to his neighbours, "What's an interested animal?"

Medea continued, "Our Sixth Principle says that no animal shall harm the environment. Our task was to evaluate whether overall there would be harm or benefit to the environment by assessing the potential environmental impact of a dam on the stream at the waterfall, and to recommend whether there should be such a dam, based on the balance between positive and negative environmental impacts."

"Our committee found that there will be a physical cost for such an enterprise. A small but not insignificant area of woods will be flooded by the dam. A corresponding area of habitat occupied by forest residents will be eliminated, and some degree of displacement can be expected. However, to place this impact in perspective, the amount of area which will be taken out of use is minimal compared to the total wooded area on the farm. In our judgment the vast area of remaining forest will be adequate to absorb the proportionately small number of inhabitants who will be forced to relocate. In this sense the impact can be characterized as one of inconvenience rather than absolute loss."

"It is also important to acknowledge the benefits of such a project, in animal and environmental terms. Indeed, because the environment includes aspects of animal culture, one could say that in many respects these two kinds of interests converge. Therefore, one may ask simply whether this project would be a net benefit to the animals at this farm. Our conclusion is that it would. The successful completion of the dam project would produce enough energy to supply Animal Farm for years to come, as well as excess energy which would be available to sell to other farms. The result is two-fold: 
energy self-sufficiency for Animal Farm, meaning the elimination of reliance upon the human power grid, and financial prosperity. Revenue from energy sales could even reduce or eliminate the need for the farm to produce other kinds of goods for sale, thus saving labour and other environmental resources. Land and water of the farm would be strained less, and animals would not be called upon to sacrifice their products for the sake of financial survival. The loss of a comparatively small area of land for the dam could relieve the pressure to harvest trees to sell on an ongoing basis, and thus result in a net gain in forest cover."

"On a comparative basis, the dam is environmentally preferable to other potential energy options, including wood, coal, oil, gas, and imported electricity. Although the capital inputs required to establish the dam are admittedly high, and thus in the short term the dam would appear to be more expensive than any of the other options, in the long term the ongoing costs for the operation of the dam are very small compared to the ongoing and increasing costs of any of the alternatives."

By this point, several of the animals had drifted off to sleep. Jessie had begun to snore so loudly that Clover, a stout motherly mare, was having difficulty hearing Medea, who spoke elegantly but quietly, so she gave the dog a gentle push with her hoof to wake him up.

Medea ignored Jessie's waking grunt, and continued, "The same can be said for impacts on the physical environment. The initial investment of environmental capital for the dam is admittedly significant. However, once that initial sacrifice is made, there is almost no ongoing or increasing physical impact, which is not the case for any of the alternatives. Consider the burning of wood, for example, which is really the only other option which could achieve energy self-sufficiency for the farm, as it is the only other energy source which is found on the property. The burning of wood would produce ongoing impact on the air of the farm and beyond, and the harvest of lumber for fuel would need to be continued indefinitely into the future, producing an ongoing, never diminishing physical impact upon the farm's wooded areas."

"It is important to give perspective to decisions of this kind. Rarely will decisions be obvious and straightforward. We have inherited a physical and financial environment which has already been adversely affected by our former masters. In this era, nature will be a nature that we make. Environmental management will consist of a series of risky experiments. The best that can be done is to reduce the risk by identifying the projects that have the best chance of producing an overall benefit to the occupants of this farm and their habitat. We have come to the conclusion that the dam is such a project, and recommend that it proceed as soon as possible." 
Napoleon stood up from his position at the right side wall. "The animals of the farm would like to thank you and your colleagues for carrying out this task for our benefit," he said graciously. And to the whole barn he said, "Is anyone aware of any errors in the report that we have just heard?"

Clover twitched her ears. All along she had thought that building a dam would be a great mistake, but she could not think of any errors in what Medea had said. So she said nothing.

"A very fine report," said Squealer, "Don't you think, friends?"

"Fine report," said a sheep, "Very fine report."

When the meeting was over, Clover took Benjamin over to the side of the barn where the Principles were written. "Read me the Sixth Principle," said Clover, "When Medea spoke of it, it sounded different than I remember it."

Benjamin read the Sixth Principle. The word 'change' had been painted over and the word 'harm' had been put in its place. "It says 'No animal shall harm the environment' just as Medea said," Benjamin reported, "but I do not think that it always said that."

Winter passed. The weather turned warmer. One evening the animals heard a commotion in the farmhouse. The animals cautiously crept to the window to look inside. Napoleon was stomping on several sheets of paper, while Snowball was prancing about the room in an agitated state. They could not make out what the quarrel was about. They found Squealer in the barn, out of harm's way. "Yes, there is a bit of a problem," she said, "We have no money to pay the bank, the power company, or Pinchfield. You see, no one has bought our milk and wool this month."

"Is there something wrong with it?" asked the other animals.

"It is too expensive," Squealer explained, "Snowball added the cost of renting the pasture to the price. No other farm has this expense, because their animals are on the Foxwood pasture. Our goods are now more expensive that those of any other farm."

Napoleon stomped into the barn. "First thing tomorrow morning," he growled, "all pasture animals will go back to Foxwood. There will be no more grazing at Pinchfield."

"But Foxwood is being destroyed. Snowball said it was wrong to..."

Napoleon interrupted them. "There will no more grazing at Pinchfield because we have no money to pay the rent. If we are to sell our goods, we have three options deplete the commons, deplete our own fields, or starve. The choice is yours." He gave the barn door a swift kick with his hind legs as he left. 
"Napoleon is frustrated," soothed Squealer, "because Snowball does not understand the Principles of Environmentalism."

"But Snowball wrote them."

"Snowball wrote them down on the side of the barn, but who do you think invented them?"

"But grazing at Foxwood will destroy the land, that's what Snowball said," said a cow.

"That land is not part of Animal Farm," explained Squealer, "And unfortunately it is going to be destroyed no matter what we do. All the other farms are sending animals there. The only thing we can do is save our own lands. We will return to Foxwood tomorrow."

A short time later, Napoleon gathered the animals together in the harness room. "I have good news and bad news. The bad news is that Snowball has had to leave the farm. The other pigs and I offered to educate Snowball on the true meaning of Environmentalism, but he refused. Unfortunately, without that training, there is no productive role for Snowball on this farm, and he is gone. The good news is that we have completed our first environmental management plan." Napoleon showed the rest of the animals a map of the farm that had been drawn on the floor with a piece of chalk. "It is past time to plan the activities on this farm properly. We have been remiss before now. We have run it better than Jones, but we can improve. This plan designates where different activities will be allowed to occur."

With a long stick clenched in one trotter he outlined the zones that would henceforth exist at the farm. "This," he said, indicating a shaded area, "is where we live. See, here is the farmhouse, the hen-house, the pens, the paddock, and the big barn. There is an urgent need for additional living space for our new animals. We are growing. We have added animals from other farms, and we have produced many offspring. Their homes will be built in this area."

"Isn't that part of the orchard?" said Jessie, sniffing the map.

"I believe it is, Jessie," said Squealer.

"Wouldn't building there mean the ecosystem would be changed?" said Muriel.

"I am not sure what you mean," said Medea, "I do not believe it will constitute harm to the environment, if that is what you mean."

"And here," continued Napoleon, "are our crop fields, here, the pastures. And here," he pointed at a large round area near the pastures, "will be the quarry."

"The quarry?" said one of the sheep, "In our pasture?" 
"Of course," said Napoleon, "It will supply the stone for the dam."

"But from our pasture?"

"The pasture is turning to rock anyway," said Medea, "It is more efficient and selfsufficient to obtain the stone from somewhere on the farm than to buy it. You are not suggesting that we use our scarce resources to buy stone, are you?"

The sheep wished he had not said anything at all.

"Here," Napoleon continued, "is the location of the dam," he poked at a spot along the ribbon that represented the stream. "And along here," he traced two lines, one from the site of the dam through the forest back to the residential zone, and the other out to the main road to the transmission lines of the human power grid, "are the routes for the transmission lines for the power from the dam."

"That's quite a large area," said Benjamin.

"It's quite a large undertaking to build a transmission line," replied Medea.

"It will run right through the middle of the woods," Benjamin said.

"Yes," said Napoleon, "And here are the wooded areas that are to be designated as Protected Heritage Old Growth Forest." He outlined two squares on the southern boundary of the farm within the forested area.

"Aren't the other areas of forest protected too?" said Clover, "What are we going to do with them?"

"Well, nothing, Clover, the designation is just a way to be exact and explicit in our planning, to be crystal clear that these areas in particular are never to be touched," Squealer explained.

"And finally," Napoleon concluded, "the dump will go here."

"The dump?" The animals were perplexed. What did they need a dump for?

"Our projects to improve the environment create materials that we need to keep away from our living areas, and our productive areas. There will be some material from the building of the dam, for instance. You do not want that put in your pens, or on the pasture, do you? Remember, dirt is something that is not where it is supposed to be. There has to be some place to put it."

Several weeks later Napoleon gathered the animals around the map. "Work is progressing nicely on the dam," he said, "It is time to purchase the machinery that will make it work. In order to do this, we will have to raise some money." He turned to the map. 
"As we have seen, these are our forested areas," he said, outlining the wide girth along three sides of the property, "and here are the Protected Heritage Old Growth Forests," again indicating the squares inside the wooded area. "We will harvest a portion of the forest, outside the protected area."

A dog whimpered. Clover and Benjamin waited for Snowball to object, forgetting that Snowball was gone. Muriel sensed their discomfort, but sought to reassure them. "It's fine, we've done this before, remember? Remember how Medea described how to cut only one tree in an area so the whole thing is sustainable?"

"Muriel is right. The whole thing will be sustainable," Napoleon said, "But it is more efficient and effective to take trees from the same area than to carry single trees all the way through the forest. Look at the First Principle. We must sustain the environment. The forest is part of the environment. We must make sure that the forest is sustained. But it does not say that the forest must never go through changes. What we must do is ensure that over time, the forest does not disappear as a resource. That means that we must replace what we take, that we must ensure that the forest renews itself so that it can be harvested again - just like the corn in our fields. We must replant trees where we cut. That is our responsibility to the land, and to ourselves, and to future generations."

"But what of the animals that live where we cut?" said one of the cows.

"We will not harvest the whole forest at once! Only one small piece at a time. When it is time to harvest more, the trees we have planted will be growing back. So there will always be trees in the forest. What could be more sustainable than that? And our friends will always have a place to move to. Our responsibility is manage this farm with care and foresight. The dam will help us achieve a bright future."

The next day, Clover was walking by the big barn when she glanced up at the Principles. Startled, she studied the wall carefully. Then she went to find Jessie.

"I cannot read the Principles," Clover said, "But it seems to me that one is missing."

Jessie looked at the list. He read:

1. Whatever sustains the environment is a friend.

2. Whatever develops, damages or destroys the environment is an enemy.

3. Everything must be considered before action is approved.

4. All animals depend on the environment.

5. No animal shall harm the environment.

"There are only five principles now," he said, "One has been taken off." 
Squealer had been watching them. She skipped from side to side and whisked her tail. "That is because the other one was too simplistic, and confused the meaning of the others."

A short time later it was announced, contrary to the original plan, that there would be a corn crop that year after all. In fact, Napoleon said, it was important to the survival of the farm that the crop be as large as possible, so that enough revenue could be earned to purchase equipment for the dam.

"It will be just one more year. It is necessary to make the initial investment of environmental capital into the dam. Then we will be in a position to focus all our resources on allowing the land to recover, because the dam will be looking after our financial requirements. This is not a backward step, just a somewhat smaller forward step than we had planned. Not everything can be completely fixed at once. The corn crop that we plant will be fertilized and sprayed less than Jones used to do. Our bureau cats have calculated that the residue from the crop will be diminished compared to crops of the past, and will not cause any undue risks to our health. Do you remember drinking that contaminated water on the day that we got rid of Jones? If we follow this path, that need never happen again.

"This is not what Jones used to do to the corn crop. There are two important differences. We are doing to spray it less and spray it better. We are going to take all the proper precautions.

"Pollution is something that is in the wrong place. We will keep the pesticide on the corn where it belongs. We will adhere to the strictest of standards for this kind of operation. I have done the guidelines myself. We will use only the best technology we can afford to carry this out. But of course, the best technology is expensive, which is one reason why we must make this crop as plentiful as we can, so that we can afford to manage the application properly"

"But the Principles prohibit this!" cried Jessie.

"Nonsense," said Medea, "The Principles set guidelines for making decisions, that is all. Each particular situation must be evaluated on its facts. To pretend that we can decide on a binding rule ahead of time, before we know what the facts are, is ridiculous!"

"But when Jones sprayed, it got into our water. We must keep the water clean!" Clover was most upset.

"At all costs, Clover?" said Napoleon, " Do you want to deny us the ability to provide for all our needs? The proper thing is to provide the greatest benefit to all of us. The most efficient way to run this farm is that which provides the greatest good to the greatest number. The pond may be a little dirty. That is a loss. But the production of 
corn is a gain. Who is to say that the pond is more valuable than corn? Who would dare to make that choice for you? Is that not a choice you would make for yourselves? Clover, would you not sooner have lots of corn to eat and clean water from Crystal Springs farm, than just a pond to drink from and no corn? Have your needs ever been neglected?" Napoleon looked shocked at the possibility, "Of course not. But if we are to be able to provide for those needs, we need to be able to earn the means by which to do so."

And thus the corn crop was planned and planted for the coming year.

Years passed. The seasons came and went, and the short animal lives fled by. A time came when there was no one who remembered the old days before the Revolution, except Clover, Benjamin and a number of the pigs. There were many more creatures on the farm now. Many animals had been born for whom the Revolution was only a dim tradition, passed on by word of mouth, and others had been bought who had never heard mention of such a thing before their arrival. The farm was more prosperous, and better organized; it had even been enlarged by two fields which had been bought from Pinchfield. The dam had been successfully completed at last, although the amount of electricity produced was not as substantial as at first had been hoped. The dam required regular repairs, which were very expensive, and during which time the farm depended on power from the human grid.

Half the forest that existed at the time of the Revolution was gone, cut and sold for revenue, or flooded by the dam. Some of the farm animals wondered about the fate of the forest animals, but no facts were available; the cats were too busy helping plan and manage the operations of the farm to waste time investigating the effects of changes that had already occurred. Their job was to predict, they said, not to reminisce.

As for the others, their life, so far as they knew, was as it had always been. Their water was brought in by truck, which filled a tank constructed in the farmyard. At first it tasted strongly of chlorine, but after a while they got used to it and then could not taste it any more. The farm had invested in the latest medical technology, and their weekly injections were over in a moment. Sometimes they thought that they did not quite feel like themselves, but when they strained to recall what it was that they were supposed to feel like, they could not remember, so decided that probably they had always felt this way after all. They seemed to have enough food - the new fields created where forest had stood before were adequate, although the grass was getting low once again.

Many of the animals had less space in their stalls, and spent more time there than they had in previous days, feeding on straw and dried pellets rather than on fresh grass and corn. The hens in particular were cooped up into very small pens indeed, in which they spent most of their days. No animal contemplated swimming in or drinking from the 
pond. It had not been officially off-limits for a very long time, but it was generally accepted that to go near it would be a foolish act indeed. It was not that the animals consciously restricted themselves - it was something that simply was not within their realm of contemplation to do. The Foxwood pasture was now dried clay and rock as were two of the farm's crop fields. They had been replaced with new fields from forested land, now cleared.

Sometimes the older animals racked their dim memories and tried to remember whether in the early days of the Revolution the condition of the farm had been better or worse than now. They could not remember. There was nothing with which they could compare its present state; they had nothing to go upon except Squealer's lists of figures, which invariably indicated that the property was being well managed. The animals found the problem insoluble. Only old Benjamin professed to remember every detail of his long life and to know that things never had been, nor ever could be, much better or much worse - the struggle for scarce resources being, he said, the unalterable law of life.

And yet the animals never gave up hope. They never lost, even for an instant, their sense of honour in being members of Animal Farm. They were still the only farm in the whole country run according to the Principles of Environmentalism. Not one of them, not even the newcomers, ever ceased to marvel at that. They found satisfaction in the knowledge that the farm had several acres of tree seedlings. These areas would never be part of the original forest ecosystem, and it would be many years before the trees would be mature, but it was an investment in the future. And when they saw the packaging on the products of Animal Farm ready for market, with the label that said "Clean and Green Products from Animal Farm - Where Nature Comes First", their hearts swelled with imperishable pride, and the talk turned towards the old heroic days, the expulsion of Jones, the writing of the Six Principles, and the great payments by which the humans had been kept at bay.

None of the old dreams had been abandoned. The Republic of Environmentalism which Major had foretold, when there would be green fields and forests where there was now pavement, was still believed in. Some day it was coming: it might not be soon, but still it was coming. On Animal Farm, decisions were made for the overall benefit of their environment. Everything was considered. No animal harmed the environment. All animals depended on the environment.

In early summer, Squealer took the sheep out to graze at the other end of the farm. They stayed there for a whole week, during which time the other animals saw nothing of them. Squealer was with them for the greater part of every day. She was, she said, teaching them about the Principles of Environmentalism, for which privacy was needed. 
It was just after the sheep had returned when the terrified neighing of a horse sounded from the entrance to the woods. Startled, the animals stopped in their tracks. It was Clover. For years, no one had seen her do more than a trot, but she was now coming towards the farm at a gallop. She neighed again, and turned around and galloped back towards the woods. The other animals ran after her. She led them through the woods in the direction of the road. As they emerged from the glade into view of a new, cleared field where forest had once stood, they saw what Clover had seen.

It was a construction site.

There were two bulldozers, a crane and several trucks surrounding the partially completed frame of an enormous building which went almost the entire length of the field. On the side of the bulldozers and crane were painted the words 'NATIONAL MALL CONSTRUCTION LTD - We Build Anywhere'. Humans in white hard hats operated the vehicles. Others were on scaffolding surrounding the frame, or standing around looking at large sheets of paper spread out on the hood of the one of the trucks. Just then, around one of the trucks came three more hard hats.

One was on a man. The others were worn by pigs.

There was a deadly silence. Amazed, terrified, huddling together, the animals watched the man show the pigs something on the large sheet of paper. It was as though the world had been turned upside down. Then there came a moment when the first shock had worn off and when in spite of everything, they might have uttered some word of objection. But just at that moment, as though at a signal, all the sheep burst out into a tremendous bleating of - "Sustainability good, sustainable development better! Sustainability good, sustainable development better! Sustainability good, sustainable development better!"

It went on for five minutes without stopping. And by the time the sheep had quieted down the chance to utter any objection had passed, for the pigs had moved on to the other side of the site.

Benjamin felt a nose nuzzling at his shoulder. He looked round. It was Clover. Her old eyes looked dimmer than ever. Without saying anything she tugged gently at his mane. They began a slow, silent walk back to the farm buildings. For a minute they stood gazing at the tarred wall where the Principles were written.

"My sight is failing," she said finally, "Even when I was young I could not have read what was written there. But it appears to me that the wall looks different. Are the Principles the same as they used to be, Benjamin?"

There was nothing now except a single Principle. It ran: 


\section{ALL ANIMALS DEPEND ON ECOSYSTEMS}

\section{BUT SOME ANIMALS DEPEND MORE THAN OTHERS}

After that it did not seem strange when all the pigs all wore hard hats. It did not seem strange to learn that the pigs had solicited bids from several development companies for the use of the land for retail and residential development. It did not seem strange when a few days later, people wearing bright orange vests, carrying tripods and strange instruments, walked around the farm for hours and spoke to each other in numbers.

The next week, a group of people went to the farmhouse door and were ushered in by Squealer. Suddenly, at the sound of the mingled voices from inside, the animals were stricken with curiosity. Such animals as were tall enough peered in the dining room window. There, round the long table, were people and pigs together. Thick folders of papers were on the table. When the company was finished with the papers, one of the men, whose name was Ramsay, stood up.

It was a source of great satisfaction to him, he said, to be able to work with the proprietors of Animal Farm towards the realization of their goals. They had demanded sustainable development, development that met needs of its present generation, without sacrificing the ability of future generations to provide for their own needs. The project on which they had now embarked would achieve that and more. It would guarantee a selfsustaining future. It would enhance their economic and social environment. It was an investment for the benefit of present and future generations of animals.

There had been a time when the respected proprietors of Animal Farm had been regarded with a certain measure of misgiving. To operate a farm on the principle of preservation of original ecosystems had been thought preposterous. But of course it had all been a misunderstanding. It was clear that the proprietors of Animal Farm simply demanded a sustainable and prosperous future. And in entering into this project, he continued, that future would be achieved, for it promised to provide Animal Farm with rental and royalty income for years to come.

"Ladies and Gentlemen," concluded Ramsay, "I give you a toast: To the success of the enterprise, and to the prosperity of Animal Farm!" There was polite applause and good natured cheering. Napoleon then said that he too had a few words to say.

He too, he said, was happy to see the joint energies of Animal Farm and Ramsay Inc. working towards a common goal. He was pleased that the misinterpretation of the principles by which the farm operated had been finally corrected. For some time there had been rumours that there was something subversive, indeed opposed to the idea of development, in the outlook of himself and his colleagues. They had been credited with attempting to change the way civilization itself did business! Nothing could be further 
from the truth. Their sole wish, now and in the past, was to achieve a prosperous future for themselves and the wider community.

There was the same polite cheering as before. But as the animals outside gazed at the scene, it seemed to them that some strange thing was happening. What was it that had altered in the faces of the pigs? Clover's old dim eyes flitted from one face to another. Some of them had five chins, some had four, some had three. But what was it that seemed to be melting and changing? Twelve voices were now chatting together, and they were all alike. No question now, what had happened to the faces of the pigs. The creatures outside looked from pig to human, and from human to pig, and from pig to human again; but already it was impossible to say which was which.

\section{THE END}

